\title{
RAZVOJ RAČUNOVODSTVA
}

Pregledni rad

UDK: 005.412:657

\section{Bernardo Aureo ${ }^{1}$}

\begin{abstract}
Apstrakt
Dvojno knjigovodstvo je nastalo pod uticajem sve razvijenijih $i$ složenijih oblika privređivanja. Njegov nastanak se vremenski vezuje za srednji vek, a prostorno za stare italijanske pomorske $i$ trgovačke gradove. Pod ovim oblikom knjigovodstva podrazumeva se svaka nastala poslovna promena u preduzeću bude evidentirana najmanje na dva računa - na levoj strani jednog i desnoj strani drugog računa. Najvažniji zadaci računovdostva se mogu svrstati u dve grupe: interne i eksterne.

Interni zadaci računovodstva su dokumentovanje (količinsko i vrednosno), kontrola nad privrednim procesima u preduzeću, kao i pružanje osnova za planiranje stanja imovine i rentabiliteta upravi preduzeća.

Eksterni zadaci su u vezi sa polaganjem računa i informisanjem, jer su preduzeća prema zakonu u obavezi da polože račune i informišu vlasnike, poverioce, zaposlene poreske organe kao $i$ ostalu zainteresovanu javnost o njihovom finansijskom $i$ prinosnom položaju.

Ključne reči: računovodstvo, knjigovodstvo, konto, interni zadaci, eksterni zadaci.
\end{abstract}

\section{Uvod}

Računovodstvo se može posmatrati kao proces u kome se prikupljaju, sistematizuju, obrađuju i čuvaju podaci i informacije. Takođe, računovodstvo se može posmatrati i kao deo preduzeća koji se njime bavi kao delatnošću, kao naučna disciplina koja unapređuje dostignuća u toj oblasti i na kraju kao nastavni predmet u školama i na fakultetima. Pravila koja su razvijena od strane računovodstvene teorije i prakse kako bi jasno definisala računovodstvene kategorije se nazivaju računovodstvena načela ili principi. Osnovna računovodstvena načela su: načelo dvostranog obuhvatanja poslovnih promena, načelo poslovne jedinice, načelo kontinuiteta, načelo poslovanja,

\footnotetext{
${ }^{1}$ Ministarstvo odbrane, Republike Angole
} 
načelo novčanog merila, načelo stvarnog troška, načelo opreznosti i načelo uzročnosti.

Ako se u obzir uzmu aktivnosti koje obavlja, knjigovodstvo se može definisati kao kontinuirani proces prikupljanja, klasifikovanja, čuvanja i izveštavanja o nastalim ekonomskim promenama na imovini preduzeća. Knjigovodstvo podrazumeva evidentiranje promena finansijske prirode $u$ poslovnim evidencijama preduzeća koje se temelje na verodostojnim knjigovodstvenim ispravama.

Glavni razlog postojanja knjigovodstva i računovodstva u bilo kom preduzeću jeste obezbeđenje podataka za efikasno upravljanje preduzećem. Dakle, ciljeve postojanja knjigovodstva i računovodstva određuju korisnici njihovih podataka i informacija.

Osnovna osobina dvojnog knjigovdstva je da se svaka nastala promena knjiži najmanje na dva računa i to: na levoj strani jednog i desnoj strani drugog računa. Druga važna osobina dvojnog knjigovodstva ogleda se u tome da je to potpun celovit računski sistem u okviru kojeg se vodi evidencija o svim promenama na sredstvima i izvorima sredstava preduzeća u toku određenog obračunskog perioda (Mihailović, Ranđelović, 2011.) Osnovni knjigovodstveni zadaci podrazumevaju obavljanje svih neophodnih poslova koji su u uskoj povezanosti sa prezentovanjem računovdstvenih informacija. Pod tim poslovima se najčešće podrazumevaju: (Škarić-Jovanović, 2016.)

- Prikupljanje neophodne dokumentacije u kojoj se nalaze finansijski podaci o stanju i promenama na imovini preduzeća;

- Kontrolisanje prikljupene dokumentacije u pogledu njene ispravnosti;

- Klasifikovanje promena po imovinskim predmetima (kontiranje);

- Evidentiranje nastalih promena u poslovnim knjigama;

- Čuvanje i arhiviranje knjigovodstvenih dokumenata i poslovnim knjiga;

- Izveštavanje o celokupnom poslovanju ili o poslovanju delova preduzeća.

Imajući u vidu zahteve koji se postavljaju pred knjigovodstvom može se reći da je značaj knjigovodstva $u$ tome što pruža informacije potrebne za utvrđivanje finansijskog rezultata preduzeća ili njegovih užih organizacionih delova, utvrđivanje finansijske strukture preduzeća, stvaranje osnova za: kontrolu raspolaganja sredstvima pojedinih delova preduzeća, kontrolu izvršenja zadataka, analizu, planiranje i alternativno poslovno odlučivanje (Nadoveza et all. 2006.). 


\section{Istorijski razvoj knjigovodstva}

Kao što je država nezamisliva bez prava, tako je i ekonomija nezamisliva bez knjigovodstva. Organski rečeno, ono je arterija i vena svakog sistema koji ekonomski egzistira. Stoga neki smatraju da je knjigovodstvo staro koliko i ljudsko društvo, jer ima za obavezu da računa, a brojanje je nastalo zajedno sa čovekom (Leblanc). Na drugoj strani nailazimo na shvatanje da je knjigovodstvo staro koliko i trgovina, jer je ona nastala društvenom podelom rada (Vlaemminck). U teoriji egzistiraju i druga shvatanja od kojih se može izdvojiti (Shussette) koji smatra da je knjigovodstvo nastalo pojavom kredita. (Nadoveza et all. 2006.) Evidentiranja za potrebe praćenja poslovnih aktivnosti počela su sa pojavom prvih preduzetnika, uglavnom trgovaca $u$ italijanskim gradovima kao što su Venecija, Đenova, Firenca i drugi. Prvobitne oblike trgovanja pratila su međusobna poznanstva između trgovaca i mušterija pa zbog toga nije bilo potrebe da se evidentiraju dužničko-poverilački odnosi između njih. Za mušteriju je bilo važno da sačuva poverenje, a trgovac da proda što više robe pouzdanoj mušteriji.

Međutim, broj mušterija je vremenom bio sve veći, a samim tim i obim prodaje, tako da trgovac nije bio u stanju sve da zapamti, a isto tako nije mogao ni da ima poverenje u ljude koje nije poznavao. Tada je već bilo neophodno da se evidentira potraživanje od kupaca za robu koja je bila prodata na poček ili na odloženo plaćanje. Takođe, to je važilo i za učinjene kratkoročne pozajmice. To vreme se vezuje za početak prostog evidentiranja odnosno prostog knjigovodstva.

Kako bi se ostvarile početne ideje o prostom knjigovodstvu, a posebno njihov dalji razvoj u pravcu stvaranja sistema dvojnog knjigovodstva neophodno je bilo da se ostvare određene pretpostavke: materijalne i nematerijalne.

Formalne pretpostavke podrazumevaju:

- Pojavu pisma (umeće pisanja);

- Pojavu brojeva (umeće računanja);

- Pojavu novca (kao sredstvo merenja vrednosti).

Materijalne pretpostavke podrazumevaju predmet i sadržinu evidencije, odnosno knjigovodstveno evidentiranje. U ove pretpostavke spadaju: (Škarić-Jovanović, 2016.) 
- Svojina nad imovinom (evidentiranje promena na sredstvima, potraživanjima, pravima i obavezama);

- Kreditni odnosi između banaka i preduzeća (poslovnih partnera);

- Razvijena trgovina, kao složeniji vid poslovanja preduzeća na lokalnim i širim tržištima;

- Kapital, kao novčani ili drugi oblici sopstvenih sredstava koji su uloženi sa namerom ostvarivanja profita.

Inače, prikazivanje nastanka i razvoja knjigovodstvene evidencije uopšte, se može sistematizovati i pratiti kroz sledeće četiri razvojne faze, i to: (Malinić, 2007.)

1. faza prostih evidencija ili faza prostog knjigovodstva;

2. faza dvojnog knjigovodstva ili sistem dvojnog knjigovodstva;

3. faza računovodstva;

4. faza savremenog sistemskog pristupa računovodstvu preduzeća.

Period od starog do 14. veka se vezuje za fazu razvoja prostog knjigovodstva. U ovako dugom vremenskom periodu, proste evidencije su se razvijale od rudimentornih oblika zapisa (početni nerazvijeni oblici beleženja, na kamenu, drvetu, glinenim pločicama) preko individualnih beleženja u prvim knjigama (podsetnicima) do dvostranih računa (konta) i kameralnog knjigovodstva.

$\mathrm{U}$ podsetniku (memorijalu, kako se u to vreme zvao), poslovne promene su evidentirane opisno, u vreme kada su nastale hronološkim redom. Međutim, kako se vremenom broj dužnika i poverilaca povećavao, a i dužničko-poverilački odnosi bivali sve češći, utvrđivanje stanja odnosa sa dužnicima ili poveriocima u memorijalu je bio sve teži. Jedino rešenje u svemu tome bilo je sastavljanje izvoda stanja (na primer dug određenog lica). Takvo sastavljanje izvoda stanja dovelo je do pojavljivanja i korišćenja tog izvoda u dvostranom obliku, za sva lica pojedinačno. Tako je pored podsetnika (memorijala) došlo do stvaranja knjige ličnih računa i knjiga blagajne i računa (konta) roba. Računi za svaku vrstu robe omogućili su da se utvrdi ostvareni finansijski rezultat. Iz svega navedenog, može se zaključiti da u fazi prostog knjigovodstva nije vođena potpuna evidncija, već je vršena evidencija samo delova imovine, obaveza, rashoda i prihoda, što je predstavljalo tešku okolnost za računanje ostvarenog rezultata.

Kameralno knjigovodstvo se primenjivalo još u srednjem veku, a predstavlja poseban oblik prostog knjigovodstva. Naziv ovog knjigovodstva potiče od latinske reči cameralia što u prevodu na srpski jezik znači državne finansije. Ovo knjigovodstvo je 
u institucijama. Zbog toga je vodilo evidnciju u planiranim i ostvarenim prihodima, planiranim i izvršenim rashodima, i imovini i dugovima. Dosta je slično prostom knjigovodstvu, samo što se kod njega glavna naslovna knjiga nazivala dnevnik uplata i dnevnik isplata i što je prilagođeno praćenju novčanih tokova javnih, vanprivrednih organizacija. Međutim, vremenom su i ove organizacije prešle na sistem dvojnog knjigovodstva, tzv. savremeno budžetsko računovodstvo, tako da se kameralno knjigovodstvo danas u praksi neupotrebljava. Daljim razvojem prostog knjigovodstva i pod uticajem sve razvijenijih i složenijih oblika privređivanja nastalo je dvojno knjigovodstvo. Nastanak ovog knjigovodstva vezuje se za srednji vek, a prostorno za već pominjane italijanske gradove Veneciju, Đenovu i druge. Prelazak sa prostog na dvojno knjigovodstvo išlo je preko tzv. «agencijskog knjigovodstva» a zatim preko tzv. «komisionog knjigovodstva». Agencijsko knjigovodstvo je vodilo knjigu blagajne, dužnika, poverilaca, a zatim i knjigu gazde, dok se komisiono knjigovodstvo vodilo kod osnivanja i poslovanja ortačkih preduzeća. Ovo knjigovodstvo je vodilo knjige (konta) robe, a zatim konta investiranog kapitala.

Sva ova poboljšanja su bila parcijalna i nisu imala celinu, odnosno merenje ostvarenog finansijskog rezultata nekog preduzeća u kontinuitetu. Zbog toga je neophodno bilo uvesti i konto kapitala vlasnika, kako bi se mogao izračunati ostvareni rezultat koji proizilazi iz vlasničkog kapitala. Na taj način je kompletiran sistem konta (računa). Takođe, kompletirana je i evidencija zahvaljujući kojoj je omogućena formalna dvojna knjigovodstvena ravnoteža, odnosno jednakost zbira dugovnih i potražnih strana u kontima glavne knjige, jednakost sa zbirom dugovne i potražne strane dnevnika kao i jednakost (uravnoteženost) bilansa stanja i bilansa uspeha. Sistem dvojnog knjigovodstva utemeljen je u prvim pisanim radovima, knjigama, u kojima se opisuje praksa i metodologija dvojnog knjigovodstva, autora Luke Parčiolija u knjizi Suma de Arithmetica, Geometria, Proportioni et Propirtionalita, izdatoj u Veneciji 1494. godina i autora Benka Kotrulića, inače poreklom iz Dubrovnika, u knjigi «O trgovini i savršenom trgovcu», pisanoj ručno 1458. godine, a štampanoj na italijanskom jeziku na osnovu kopije iz Dubrovnika tek 1582. godine. Radovi ovih autora imali su značajan uticaj na praksu i uvođenje dvojnog knjigovodstva i u drugim zemljama - Nemačkoj, Francuskoj, Engleskoj, Holandiji i drugim zemljama (Malinić, 2007.).

Suština prethodno navedenih pisanih radova bila je da je osnovna karakteristika dvojnog knjigovodstva vođenje sledećih poslovnih knjiga:

- memorijal, u kojoj su opisano zapisivani poslovni događaji onim redom kako su nastajali; 
- dnevnik u kome su hronološkim redom evidentirane nastale poslovne transakcije i

- glavna knjiga u kojoj su organizovana sistemska knjiženja na otvorenim računima (kontima).

Knjiženja su prvo evidentirana u dnevniku, koji je sadržao kolone za datum, opis promene i dvostruku kolonu za iznos (duguje i potražuje), a zatim su ovako knjižene poslovne promene iz dnevnika prenošene na odgovarajuća konta glavne knjige. Glavna suština dvojnog knjigovodstva ovog vremena su pravila za knjiženje i načini knjiženja na različitim kontima kao i sastavljanje bilansa.

Pravila za knjiženje su se izvodila iz stava da su u pitanju lični računi personifikacija računa (konta) iz čega je proizašlo pravilo: ko prima duguje, a ko daje potražuje, ali već u 17. veku koriste se i druga konta (računi) i druge klasifikacije, kao što su: račun kapitala ili vlasnika, računi stvari, računi korespodenata i druge vrste. Pomenuto pravilo kod ličnih računa, nije moglo biti primenjeno kao objašnjenje za knjiženje rashoda i prihoda i finansijskog rezultata - dobitka ili gubitka jer iza njih nisu postojala primanja i davanja, ali se ipak osnovni zahtev pri knjiženju u dvojnom knjigovodstvu sastoji u činjenici da jedna poslovna promena izaziva potrebu za dvojnim, dvostrukim knjiženjem na dva različita konta i to tako što će jedan konto ili više konta «dugovati», a istovremeno za isti iznos drugi konto ili druga konta «potraživati».

\section{Perspektive u razvoju računovdostva}

Osnovna karekteristika 21. veka jesu česte i turbulentne promene koje se kako u svetu, tako i u Srbiji, dešavaju. Promene su često demografske prirode (na primer, povećana potrošnja po glavi stanovnika), zatim produžetak radnog veka, povećanje produktivnosti rada i smanjenje resursa. Povećanje produktivnosti rada nastalo je usled automatizacije, a što je dovelo do viška radne snage i skraćivanje radnog vremena. Sve veće povećanje obima proizvodnje dovelo je do zagađenja životne sredine u okolini preduzeća. (Brili et all, 2010.).

Računovodstvo je samo po sebi interesantna ekonomska aktivnost, koja ako se obavlja savremenim sredstvima ima smisla i postoji zahvaljujući promenama. Promene su za računovodstvo od izuzetne važnosti. Zahvaljujući pre sveta promenama, koje su u osnovi i prirodi računovdstva, ono se može razvijati u nedogled. Suprotno, računovodstvo bi bilo samo meta svih opasnosti koje napadaju savremeno privređivanje. Zbog toga se, danas, od računovođa očekuje da brzo, 
kvalitetno i odgovorno prilagode i reaguju u cilju održavanja profesionalnog ugleda kako sebe kao ličnosti tako i za preduzeće za koje obavljaju poslove. Razvojem računovodstva neophodno je konstantno uviđanje promena i težnja za što boljim i kvalitetnijim informacijama. U uslovima kada se sve svakodnevno menja nemoguće je učiniti računovodstvo stalnim. Zbog toga bi, neki od važnijih principa kojima se treba upravljati prilikom razvoja računovodstva u budućnosti bili:

- Sve prolazi. Način vođenja knjiga i kontrola poslovanja u savremenim uslovima poslovanja enormnom brzinom se menjaju. Neophodno je shvatiti i pomiriti se sa činjenicom da sve što postoji, jednog dana će da prođe. Tako i živa bića, ljudi, a posebno računovodstvo.

- Sve ima svoj rok trajanja. Sve što postoji na ovome svetu, postoji u određeno vreme i na određenom mestu. Ukoliko se pogrešne stvari rade u pogrešno vreme $\mathrm{i}$ na pogrešnom mestu, kao posledicu će imati nepovoljan krajnji rezultat.

- Ništa ne postoji samo od sebe. Preduzeća koja razumeju ovu aksiomu, da ništa ne postoji samo po sebi, su mnogo fleksibilnija u stavovima i u stanju su da shvate da je realnost tu u sadašnjem trenutku, a ne u nekom drugom vremenu koje postiji u njihovim mislima.

Pored svakodnevnih promena, kojima se preduzeća moraju prilagođavati i funkcionisati prema njima, neophodno je posedovati i stručna lica iz oblasti informacionih tehnologija. Informacione tehnologije u računovodstvu su novijeg datuma. Koriste se poslednjih nekoliko godina uglavnom kao zamena za termine računarstvo i informatika, mada se ne mogu sasvim smatrati sinonimima. Opšte je poznat i nesporan značaj kvalitetnih i pouzdanih informacija za uspeh u upravljanju i sprovođenju ciljeva preduzeća. Posebna uloga $u$ tome, naravno pripada računovodstvenim podacima i pokazateljima. Informacije, kao proizvod informacionih tehnologija, kako danas, tako će sigurno i u dalekoj budućnosti biti strategijski resurs od izuzetne važnosti za organizaciju i funkcionisanje preduzeća. Zbog toga je neophodno da informacione tehnologije u preduzećima u budućnosti imaju savremen upravljački pristup. Imajući u vidu značaj informacionih tehnologija za računovodstvo savremenih preduzeća, od velike važnosti bi bilo da se i u daljoj budućnosti na što adekvatniji način i što više prilagode primenama u ukupnom struktuiranju preduzeća kao i njegovom funkcionisanju. Kako bi se ovo što uspešnije realizovalo, neophodno je izvršiti reorganizovanje instrumenata računovodstvene organizacije, a s tim u vezi i celokupne računovodstvene funkcije. Takođe, kada su u pitanju zaposleni u računovodstvu preduzeća neophodno je sve više usavršiti njihovo obrazovanje, posebno iz oblasti informatike. Računovođa bi trebalo da postane neposredni korisnik savremenih infomacionih tehnologija, što je posledica stalnog 
dodatnog formalnog i neformalnog informatičkog obrazovanja. Ovo bi trebalo da se odnosi, ne samo na zaposlene u oblasti računovodstva, već i na menadžere i izvršne strukture u svakom preduzeću. Zahvaljujući savremenim računarima, može se daleko brži i efikasnije knjigovodstveno obraditi daleko veći broj knjigovodstvenih dokumenata i poslovnih promena, a isto tako i sastaviti i prezentovati mnogobrojni i različiti računovodstveni izveštaji.

Savremeni računari mogu da obavljaju računovodstvene procedure pomoću odgovarajućih računovodstvenih programa. Takođe, pored ovih tzv. aplikativnih programa, zahvaljujući savremenim sistemskim programima ili softverima, obavljanje računovodstvenih poslova u budućnosti će biti daleko lakše. Savremeni računari i sa njima $u$ vezi informacione tehnologije, zahtevaće $i$ nov pristup u organizaciji računovodstvene funkcije, dok u potpunosti ne preuzmu računovodstvene poslove. Pre svega, u potpunosti će nestati (ili se bar značajno smanjiti) upotreba dnevnika, oslabiće značaj dokumentacije izuzev verifikacione funkcije, povećaće se uloga računovodstvenih izveštaja posebno za potrebe internih korisnika. Brzim razvojem informacionih tehnologija aplikativni programi (softveri) su sve kvalitetniji i brži, ali i primenjiviji za korisnike što za posledicu ima širenje broja korisnika savremenih računara u okviru preduzeća. Sve većom upotrebom računara u preduzećima posebno je došlo do izražaja rešavanje problema u okviru računovodstveno - finansijskih i administrativnih aktivnosti preduzeća. U budućnosti će, baza računovodstvene aktivnosti, posebno one $u$ vezi sa obradom računovodstvenih podataka i računovodstvenih izveštaja, dominantnu će ulogu imati specijalizovani računovodstvni softveri. Zbog toga je bitno da ova vrsta softvera u svakom preduzeću ispunjava bar minimum standardnih zahteva, ali i da bude proizvedena od strane pouzdanog proizvođača.

\section{Zaključak}

Dakle, na kraju može se doneti zaključak da će samo aplikativni programi (softveri) u budućnosti biti od velike važnosti za menadžere u računovodstvu svakog preduzeća. Značaj ovih programa se može posmatrati sa dve tačke gledišta. Kao prvo, menadžer u računovodstvu će morati da formira adekvatan algoritam zahteva koji ima veze sa kompjuterizovanom organizacijom, a kao drugo, ovaj menadžer će morati da obezbedi računovodstvo strogo formalizovan sistem, potrebno je izvršiti odgovarajuću standardizaciju šire problematike računovodstvenog softvera, odnosno izvršiti strog odabir proizvođača i isporučioca softvera kao i korisnike tog softvera. Trend razvoja i primene računarske obrade podataka u računovodstvu potencira detaljno i šire poznavanje ukupne problematike računovodstvenog softvera $u$ 
savremenoj računovodstvenoj funkciji savremenih preduzeća i privrednih subjekata uopšte.

U dinamičnim uslovima poslovanja, računovodstvo, obogaćeno informacionim tehnologijama u uslovima realnog vremena i just in time koncepta obezbediće istinite i realne informacije o poslovanju preduzeća.

\title{
Literatura
}

1. Brili A. Ričard, Majers K. Stjuart, Markus DŽ. Alan, 2010. Osnovi korporativnih finansija, MATE, Beograd.

2. Majstorović A., Milojević I., 2008. Računovodstvo, Univerzitet Privredna akademija Novi Sad.

3. Malinić D. S., 2007. Osnove računovodstva, Univerzitet Braća Karić, Beograd.

4. Nadoveza B., Majstorović A., Milojević I., 2006. Računovdostvo i upravljanje troškovima, Mladost biro, Beograd.

5. Škarić Jovanović K., 2016. Finansijsko računovodstvo, Ekonomski fakultet, Beograd.

\section{DESENVOLVIMENTO DA CONTABILIDADE}

\section{Bernardo Aureo ${ }^{2}$}

\begin{abstract}
Abstrato
Dupla escrituração surgiu por influencia de todas mais desenvolvidas e organizadas areas economicas. Sua origem actualmente liga-se a idade media, uma antiga espaçosa marítima italiana e cidades comerciais. Nesta area de contabilidade entende-se que toda existencia de mudanca de negocios na empresa evidencia-se pelo menos em duas contas - no lado esquerdo e no lado direito da outra conta.

As tarefas mais importantes da contabilidade podem ser classificar-se em dois grupos: internos e externos.

Tarefas internas da contabilidade sao a documentação (volume e valor), o controle sobre os processos de negócio na empresa, bem como proporcionar uma base para o planejamento de ativos e gestão de rentabilidade da empresa.
\end{abstract}

\footnotetext{
${ }^{2}$ Ministério da Defesa da República de Angola
} 
Tarefas externas estão relacionadas com o deposito de conta e informação, porque as empresas são obrigadas por lei a depositar as contas e informar os proprietários, credores, empregados, autoridades fiscais e outros públicos interessados sobre a sua situação financeira e de rendimento.

Palavras-chave: contabilidade, escrituração e, conta.

Rad primljen:14.07.2016. godine

Rad prihvaćen: 22.09.2016. godine 